\title{
Culture and sexual differences in impulsivity among university students
}

\author{
Khaled Elsayed Ziada', Salaheldin Farah Bakhiet ${ }^{2}$, Ahmed Al-Shafey ${ }^{3}$
}

\begin{abstract}
The aim of the present study was to examine Culture and sexual differences in impulsivity among university students using The Barratt Impulsiveness Scale (BIS-11). In this study we used two samples, one from Egyptian $(\mathrm{N}=450)$ and one from Saudi Arabian $(\mathrm{N}=396)$ university students, to close this gap and to observe differences between sexes and cultures. Cultural differences were found with on average impulsivity in Saudi Arabia than in Egypt. Sex differences differed not only in magnitude but also in direction. Males showed on average higher impulsivity in Saudi Arabia but females in Egypt. Differences were larger between cultures than between sexes. Indications for further research are discussed.
\end{abstract}

Keywords: Impulsivity, Cross-cultural, Sexual differences, Egypt, Saudi Arabia, Students.

${ }^{1}$ Department of Psychology- Faculty of Arts -Menoufia UniversityEgypt

${ }^{2}$ King Saud University- Riyadh - University of Khartoum- Sudan

${ }^{3}$ Department of Psychology- Helwan University- Egypt

(Culture and sexual differences ...) Khalid Ziada- Salaheldin Bakhiet - Ahmed Al-Shafey 


\section{Culture and sexual differences in impulsivity among university}

\section{students}

\section{Introduction}

\subsection{State of research}

Impulsivity was defined as a "construct relevant to explaining both normal individual differences in personality and more extreme personality pathology among clinical populations" (Stanford, Mathias, Dougherty, Lake, Anderson, \& Patton, 2009). It was described as the decisive factor leading from high anger to physical violence (Ammerman, Kleiman, Uyeji, Knorr, \& McCloskey, 2015), reactive and proactive aggression (Hecht \& Latzman, 2015). The impulsivity dimension negative urgency was found to be associated with negative effects like a poor sense of self and disruptions in thinking, the dimension premeditation into a positive association with energetic affects and forth effort, and completing activities can be disturbed by a lack of perseverance, whereas seeking for sensations generates positive effects and leads to enjoying oneself (Sperry, Lynam, Walsh, Hortond, \& Kwapil, 2016). Links between impulsivity and borderline or antisocial personality features as well as alcohol consumption have been found. Associations with both antisocial and borderline personality features have been found by Hahn, Simons, and Hahn (2016), Maneiro, Gómez-Fraguela, Cutrín, and Romero (2017), and Wardell, Quilty, and Hendershot (2016). It was also reported 
that impulsivity is associated positively with sadistic and passiveaggressive personality disorders and indecisiveness (BarkleyLevenson \& Fox, 2016; Velotti \& Garofalo, 2015), and negatively with individual results of intelligence tests (more precisely the APM) via the item-position effect (Lozano, 2015). Conversely, general cognitive ability and slow life history strategy encourage behavioral self-regulation, which in turn reduces socially antagonistic attitudes and behaviors (Wenner, Bianchi, Figueredo, Rushton, \& Jacobs; 2013).

Differences between the sexes are likely. In a theoretical approach, Weinstein and Dannon (2015) argued that, from an evolutionary perspective, females can be less impulsive than males but only during the fertile stages of the menstrual cycle. But what does empirical research say? In a huge meta-analysis of 741 effect sizes from 277 studies, Cross, Copping and Campbell (2011) found significantly higher values for the impulsivity linked traits sensation seeking $(d=0.41)$ and behavioral risk taking $(d=$ 0.36) in males. Simultaneously, the estimated effect size of sex in effortful control, where males performed weaker than females, was only small $(d=0.08)$. It was undetectable in delay discounting and executive function tasks. Another review of related studies was done by Weafer and de Wit (2014). Therein, behavioral measures of impulsive actions showed sex differences in different directions, depending on the task. Two of three measures of go/no-go tasks showed higher impulsivity in males (Culture and sexual differences ...) Khalid Ziada- Salaheldin Bakhiet - Ahmed Al-Shafey 
and one no differences, in stop-tasks a higher impulsivity in females could be found in five of ten measurements whereas the remaining ones showing no differences, and in four measurements of continuous performance task, males showed higher impulsivity than females in two cases, females higher than males in one case, and in another case no differences were found. Mixed results were also found by Malesza and Ostaszewski (2016), with higher means of males than females on the impulsivity scale of Eysenck's conception of impulsivity in a German sample but differences were not significant, and by Cyders (2013), who reported significantly higher values of males than females within the impulsivity dimensions positive urgency and sensation seeking, whereas sex differences on the dimensions lack of deliberation, negative urgency, and lack of perseverance were zero or non-significant.

Furthermore, significant sex differences in various measurements of impulsivity in favor of males were found across different cultures by Chapple and Johnson (2007) in a sample of US children from the National Longitudinal Survey of Youth (NLSY79), by Yago, Hirose, Kawamura, Omori, and Okamitsu (2015) for Japanese toddlers, by Hadiyono and Kahn (2010) for both American and Indonesian students, by Magnússon, Smári, Grétarsdóttir, and Prándardóttir (1999) for Icelandic children, and by Burns, Walsh, Gomez, and Hafetzor (2006) for both American and Malaysian children. Brewis, Schmidt, and Sánchez Casas 
(2003) reported higher scores for girls than boys in impulse control in a US sample but no sex differences in a Mexican sample.

This allows the assumption that sex differences in impulsivity are in favor of males and largely stable across cultures, but most of the available studies were done in Western countries. For example, of the 277 studies included in the meta-analysis of Cross et al. (2011), only 11 observed samples from Asia, Africa and the Middle East. In addition, there are also studies which show significant differences between cultures. Cozzi et al.(2013) estimated higher impulsivity in Italian toddlers compared to US toddlers, Chahin, Cosi, Lorenzo-Seva, and Vigil-Colet (2010) observed significantly higher values for motor impulsiveness and lack of planning in a Colombian sample compared to a Spanish sample, and Eysenck and Jamison (1986) found significantly higher values of impulsivity for American than British children.

\subsection{Primary aims}

The basic aim of this study was to examine differences in impulsivity between cultures, in this case Egypt and Saudi Arabia, and sexes, in general and in particular in the performance on the Barratt Impulsivity Scale (BIS-II). We would like to contribute to the closure of the gap in knowledge about gender differences in Arabian or Middle Eastern countries. The first hypothesis we want to examine is that there are cultural differences in impulsivity between Egypt and Saudi Arabia. The second (Culture and sexual differences ...) Khalid Ziada- Salaheldin Bakhiet - Ahmed Al-Shafey 
hypothesis postulates that males score significantly higher than females on measures of impulsivity. Hypothesis number three is the possibility of significant cultural differences in magnitude and direction of sex differences. Fourth, we want to see whether sex differences are stronger than cultural differences, because crosscultural differences in personality traits are often relatively small (Allik, 2005). The last hypothesis is proposed because Egypt and Saudi Arabia are societies with similar language, traditions and religion.

\section{Method}

\subsection{Measurement of impulsi vity}

The Barratt Impulsiveness Scale, version II (BIS-II), was used as a tool to measure impulsivity. The first version of this scale was created by Ernest S. Barratt in 1959, then revised several times (e.g., Patton, Stanford, \& Barratt, 1995) until the last version by Stanford et al. in 2009. The BIS-II uses 30 items grouped into first and second order subscales, as well as the sum of second order factors in a total score. The first order subscales measure the factors: attention by five items, motor by seven, self-control by six, cognitive complexity by five, perseverance by four, and cognitive instability by three. The second order subscales measure the traits: attentional impulsiveness by eight items, motor impulsiveness by eleven, and non-planning impulsiveness by eleven. Thereby, items for first order factors were assembled via principal components analysis (PCA).

(Culture and sexual differences ...) Khalid Ziada- Salaheldin Bakhiet - Ahmed Al-Shafey 
Stanford et al. (2009) successfully proved the internal consistency and the test-retest reliability with a Cronbach's $\alpha$ and Spearman's $\rho$ of .83 for the total score. In this study, the reliability reached a Cronbach's $\alpha$ based on standardized items of .78. The reliability of the BIS-11 estimated by the use of the answers given by the samples from Egypt and Saudi Arabia is overall good and comparable . Cronbach's $\alpha$ is between .74 and .76 for the total score (Table 1 ).

Table 1 Cronbach's $\alpha$ values for first-and second order factors of the BIS11 from the combined and the separated samples used in this study

\begin{tabular}{|c|l|l|l|}
\hline \multicolumn{2}{|c|}{ Factors } & \multicolumn{2}{c|}{ Samples } \\
\hline \multirow{3}{*}{ Order } & Scale & Egyptian & \multicolumn{1}{|c|}{$\begin{array}{c}\text { Saudi } \\
\text { Arabian }\end{array}$} \\
\hline \multirow{4}{*}{ First } & Attention & .62 & .23 \\
\cline { 2 - 4 } & Motor & .52 & .71 \\
\cline { 2 - 4 } & Self-control & .60 & .16 \\
\cline { 2 - 4 } & Cognitive complexity & .19 & .31 \\
\cline { 2 - 4 } & Perseverance & .6 & .34 \\
\cline { 2 - 4 } & Cognitive instability & .36 & .46 \\
\hline \multirow{5}{*}{ Second } & Cognitive impulsiveness & .65 & .43 \\
\cline { 2 - 4 } & Motor impulsiveness & .53 & .70 \\
\cline { 2 - 4 } & Non-planning impulsiveness & .52 & .32 \\
\cline { 2 - 4 } & Total & .75 & .74 \\
\hline
\end{tabular}

However, strong variations were found between the factors and also between the samples with, in part, extremely low values, especially for cognitive complexity (.19 to .31 ) and perseverance (Culture and sexual differences ...) Khalid Ziada- Salaheldin Bakhiet - Ahmed Al-Shafey 
(.06 to .34). These findings must be considered when evaluating the results.

The suitability of the BIS for identification of impulsive individuals and detection of individual personality differences was also successfully tested in comparison to other measurements of the same traits by Kulendran, Patel, Darzi, and Vlaev (2016) and by Moreno1, Iza, Dolado, and Palomo (2011).

\subsection{Sample}

The Egyptian sample was drawn randomly from the Faculties of Education and Arts at the University of Kafrelsheikh. The total sample of 450 students consisted of 237 female ( 53\%) and 213 male $(\sim 47 \%)$ students, with mean age of $20.1 \mathrm{y}(S D=1.0)$. The Saudi sample of 396 university students came from King Saud University College of Education was drawn randomly and contained 206 female $(\sim 52 \%)$ and 190 male ( 48\%) students, with mean age of $21.2 \mathrm{y}(\mathrm{SD}=1.9)$. Thus, the gender ratio in both samples is almost balanced. At both universities, participation took place randomly and on a voluntary basis without payment. Students were tested in their classrooms after agreeing in writing to participate in the study. In both samples, the students were tested in sessions of about 15 to 20 minutes by using a pen and paper test.

\subsection{Note on Interpretation}

We decided to use alternative and more critical conventions for interpretation of effect-sizes, in this case Cohen's d, suggested by Ferguson (2009). These are (-)0.41 to declare an effect as significant, (-)1.15 as moderate, and (-)2.70 as strong. The reasons behind this decision were the acceptable but not good Cronbach's $\alpha$ of the BIS in this study and the missing comparative studies with samples from Egyptian or Saudi Arabian culture. Alternative conventions should help to avoid premature conclusions from the results.

(Culture and sexual differences ...) Khalid Ziada- Salaheldin Bakhiet - Ahmed Al-Shafey 


\section{Results}

\subsection{Full sample}

Table 1 shows descriptive results for the Egyptian and Saudi Arabian total, male, and female samples, for all six first order and all three second order factors as well as the total score, calculated from second order factors. The small standard errors across all factors and samples point to accurate estimates of the mean values.

Table 2: Descriptive statistics of main results of the Egyptian $(N=$ 213 males +237 females $)$ and Saudi Arabian $(N=190$ males + 206 females) sample.

\begin{tabular}{|c|c|c|c|c|c|c|c|c|c|c|c|}
\hline \multicolumn{2}{|r|}{ Factors } & \multirow{2}{*}{ Culture } & \multicolumn{3}{|c|}{ Total } & \multicolumn{3}{|c|}{ Males } & \multicolumn{3}{|c|}{ Females } \\
\hline Order & Scale & & $M$ & $S D$ & $S E$ & $M$ & $S D$ & $S E$ & $M$ & $S D$ & $S E$ \\
\hline \multirow{12}{*}{ First } & \multirow{2}{*}{ Attention } & EGY & 10.19 & 2.81 & .13 & 10.21 & 3.11 & .21 & 10.19 & 2.52 & .16 \\
\hline & & SAU & 11.30 & 3.60 & .18 & 11.72 & 4.35 & .32 & 10.91 & 2.67 & .19 \\
\hline & \multirow{2}{*}{ Motor } & EGY & 13.89 & 3.44 & .16 & 13.87 & 3.59 & .25 & 13.90 & 3.31 & .22 \\
\hline & & SAU & 15.65 & 4.77 & .24 & 16.02 & 5.05 & .37 & 15.30 & 4.48 & .31 \\
\hline & \multirow{2}{*}{ Self-control } & EGY & 12.14 & 3.53 & .17 & 11.19 & 3.53 & .24 & 13.04 & 3.20 & .21 \\
\hline & & SAU & 14.25 & 3.46 & .17 & 14.18 & 3.76 & .27 & 14.32 & 3.16 & .22 \\
\hline & \multirow{2}{*}{$\begin{array}{l}\text { Cognitive } \\
\text { complexity }\end{array}$} & EGY & 12.04 & 2.54 & .12 & 11.54 & 2.50 & .17 & 12.46 & 2.49 & .16 \\
\hline & & SAU & 11.13 & 3.05 & .15 & 11.68 & 3.31 & .24 & 10.63 & 2.70 & .19 \\
\hline & \multirow{2}{*}{ Perseverance } & EGY & 6.93 & 1.84 & .09 & 6.99 & 1.93 & .13 & 6.86 & 1.75 & .11 \\
\hline & & SAU & 8.93 & 2.28 & .11 & 9.53 & 2.51 & .18 & 8.38 & 1.88 & .13 \\
\hline & \multirow{2}{*}{$\begin{array}{l}\text { Cognitive } \\
\text { instability }\end{array}$} & EGY & 7.28 & 1.94 & .09 & 7.44 & 1.97 & .14 & 7.13 & 1.91 & .12 \\
\hline & & $\overline{S A U}$ & 7.52 & 2.02 & .10 & 7.53 & 2.18 & .16 & 7.51 & 1.87 & .13 \\
\hline \multirow{8}{*}{ Second } & \multirow{2}{*}{$\begin{array}{l}\text { Cognitive } \\
\text { impulsiveness }\end{array}$} & EGY & 17.47 & 3.98 & .19 & 17.65 & 4.35 & .30 & 17.31 & 3.61 & .24 \\
\hline & & SAU & 19.22 & 3.80 & .19 & 19.85 & 4.40 & .32 & 18.65 & 3.04 & .21 \\
\hline & \multirow{2}{*}{$\begin{array}{l}\text { Motor } \\
\text { impulsiveness }\end{array}$} & EGY & 20.82 & 4.35 & .21 & 20.86 & 4.51 & .31 & 20.78 & 4.21 & .27 \\
\hline & & SAU & 25.05 & 5.10 & .26 & 26.23 & 5.34 & .39 & 23.96 & 4.63 & .32 \\
\hline & \multirow{2}{*}{$\begin{array}{l}\text { Non-planning } \\
\text { impulsiveness }\end{array}$} & EGY & 24.19 & 4.70 & .22 & 22.73 & 4.77 & .33 & 25.50 & 4.24 & .28 \\
\hline & & SAU & 25.81 & 4.14 & .21 & 26.32 & 4.56 & .33 & 25.33 & 3.67 & .26 \\
\hline & \multirow{2}{*}{ Total score } & EGY & 62.48 & 10.19 & .48 & 61.24 & 11.09 & .76 & 63.59 & 9.19 & .60 \\
\hline & & SAU & 70.08 & 10.37 & .52 & 72.41 & 11.58 & .84 & 67.93 & 8.60 & .60 \\
\hline
\end{tabular}




\subsection{Cross-cultural differences}

Table 2: Descriptive statistics of cultural differences between the total Egyptian sample (EGY) and the total Saudi Arabian sample (SAU) $(d f=844)$. Positive numbers for $\Delta$ and $d$ represent higher values in the Egyptian sample, negative numbers higher values in the Saudi Arabian sample.

\begin{tabular}{|c|c|c|c|c|c|c|c|c|}
\hline \multicolumn{2}{|c|}{ Factors } & \multicolumn{2}{|c|}{$M$} & \multirow{2}{*}{$\begin{array}{l}S D \\
\Delta\end{array}$} & \multicolumn{2}{|c|}{$\begin{array}{c}\text { t-test for equality } \\
\text { of means }\end{array}$} & \multicolumn{2}{|c|}{$\begin{array}{l}\text { Levene's Test for } \\
\text { equality of } \\
\text { variances }\end{array}$} \\
\hline Order & Scale & $\Delta$ & $d$ & & $t$ & $p$ & $F$ & $p$ \\
\hline \multirow{6}{*}{ First } & Attention & -1.11 & -0.35 & -0.78 & -4.993 & $<.001$ & 0.373 & .542 \\
\hline & Motor & -1.76 & -0.43 & -1.33 & -6.191 & $<.001$ & 21.653 & $<.001$ \\
\hline & Self-control & -2.11 & -0.60 & 0.07 & -8.798 & $<.001$ & 22.154 & $<.001$ \\
\hline & $\begin{array}{l}\text { Cognitive } \\
\text { complexity }\end{array}$ & 0.91 & 0.33 & -0.51 & 4.702 & $<.001$ & 1.868 & .172 \\
\hline & Perseverance & -2.00 & -0.97 & -0.44 & -14.166 & $<.001$ & 2.711 & .100 \\
\hline & $\begin{array}{l}\text { Cognitive } \\
\text { instability }\end{array}$ & -0.24 & -0.12 & -0.08 & -1.775 & $<.001$ & 0.347 & .556 \\
\hline \multirow{4}{*}{ Second } & $\begin{array}{c}\text { Cognitive } \\
\text { impulsiveness }\end{array}$ & -1.75 & -0.45 & 0.18 & -6.542 & $<.001$ & 3.830 & .051 \\
\hline & $\begin{array}{c}\text { Motor } \\
\text { impulsiveness }\end{array}$ & -4.23 & -0.89 & -0.75 & -13.009 & $<.001$ & 9.468 & .002 \\
\hline & $\begin{array}{l}\text { Non-planning } \\
\text { impulsiveness }\end{array}$ & -1.62 & -0.37 & 0.56 & -5.276 & $<.001$ & 14.995 & $<.001$ \\
\hline & Total score & -7.60 & -0.74 & -0.18 & -10.730 & $<.001$ & 0.197 & .657 \\
\hline
\end{tabular}

In table 2, differences of factors between the two cultural samples were calculated and controlled. Positive numbers represent higher values in the Egyptian sample, negative differences higher values in the Saudi Arabian sample. The same applies to Cohen's d. tstatistic for equality of means are shown in columns seven and eight with $\mathrm{df}=844$. Considering both $\mathrm{p}$ - and $\mathrm{d}$-values as criteria, Saudi Arabian students showed significant higher means in the 
following factors, in order of effect size: perseverance $(\Delta \mathrm{M}=$ $2.00 ; \mathrm{d}=-.97 ; \mathrm{t}=-14.166 ; \mathrm{p}<.001)$, motor impulsiveness $(\Delta \mathrm{M}=$ $-4.23 ; \mathrm{d}=-0.89 ; \mathrm{t}=-13.009 ; \mathrm{p}<.001)$, self-control $(\Delta \mathrm{M}=-2.11$; $\mathrm{d}=-0.60 ; \mathrm{t}=-8.798 ; \mathrm{p}<.001)$, cognitive impulsiveness $(\Delta \mathrm{M}=-$ $1.75 ; \mathrm{d}=-0.45 ; \mathrm{t}=-6.542 ; \mathrm{p}<.001)$, and motor $(\Delta \mathrm{M}=-1.76 ; \mathrm{d}=$ $-0.43 ; \mathrm{t}=-6.191 ; \mathrm{p}<.001)$. This resulted also in a higher total score of Saudi Arabian students $(\Delta \mathrm{M}=-7.60 ; \mathrm{d}=-0.74 ; \mathrm{t}=$ $10.730 ; \mathrm{p}<.001)$. Differences of standard deviations between the two samples were also detectable but mostly at a non-significant level. Using Levene's Test for equality of variances, we found significant differences in the case of motor $(\triangle \mathrm{SD}=-1.33 ; \mathrm{F}=$ $0.373 ; \mathrm{p}<.001)$, self-control $(\Delta \mathrm{SD}=0.07 ; \mathrm{F}=22.154 ; \mathrm{p}<.001)$, motor impulsiveness $(\Delta \mathrm{SD}=-0.75 ; \mathrm{F}=9.468 ; \mathrm{p}=.002)$, and nonplanning impulsiveness $(\Delta \mathrm{SD}=0.56 ; \mathrm{F}=14.995 ; \mathrm{p}<.001)$. Most standard deviations were higher in the Saudi Arabian sample, but non-significant for the total score $(\Delta \mathrm{SD}=-0.18 ; \mathrm{F}=0.197 ; \mathrm{p}=$ $.657)$.

\subsection{Sex differences}

Sex differences in means and standard deviations, separately for the Egyptian and Saudi Arabian samples, can be seen in tables 3 and 4. Positive numbers of differences represent higher values in the male sample, negative differences higher values in the female sample. The same applies to Cohen's d. p-values for differences between means and t-statistic for equality of means are shown in columns seven and eight, for standard deviations in nine and ten, with df $=447$ to 448 for Egypt and df = 394 for Saudi Arabia. 
Table 3: Descriptive statistics of sexual differences within the Egyptian sample $(N=213$ males and $N=237$ females, $d f=447$ to 448). Positive numbers for $\Delta$ and $d$ represent higher values in the male sample, negative numbers higher values in the female sample.

\begin{tabular}{|c|c|c|c|c|c|c|c|c|}
\hline \multicolumn{2}{|c|}{ Factors } & \multicolumn{2}{|c|}{$M$} & \multirow{2}{*}{$\begin{array}{c}S D \\
\Delta \\
\end{array}$} & \multicolumn{2}{|c|}{$\begin{array}{l}\text { t-test for equality } \\
\text { of means }\end{array}$} & \multicolumn{2}{|c|}{$\begin{array}{c}\text { Levene's Test for } \\
\text { equality of } \\
\text { variances }\end{array}$} \\
\hline Order & Scale & $\underline{\Delta}$ & $d$ & & $t$ & $p$ & $F$ & $p$ \\
\hline \multirow{6}{*}{ First } & Attention & 0.02 & 0.01 & 0.59 & 0.061 & .951 & 10.190 & .002 \\
\hline & Motor & -0.03 & -0.01 & 0.28 & -0.090 & .928 & 0.442 & .506 \\
\hline & Self-control & -1.85 & -0.55 & 0.34 & -5.840 & $<.001$ & 0.633 & .427 \\
\hline & $\begin{array}{l}\text { Cognitive } \\
\text { complexity }\end{array}$ & -0.92 & -0.37 & 0.01 & -3.909 & $<.001$ & 0.299 & .585 \\
\hline & Perseverance & 0.13 & 0.07 & 0.18 & 0.751 & .453 & 1.357 & .245 \\
\hline & $\begin{array}{l}\text { Cognitive } \\
\text { instability }\end{array}$ & 0.31 & 0.16 & 0.06 & 1.665 & .097 & 0.871 & .351 \\
\hline \multirow{4}{*}{ Second } & $\begin{array}{c}\text { Cognitive } \\
\text { impulsiveness }\end{array}$ & 0.34 & 0.09 & 0.74 & 0.904 & .366 & 7.317 & .007 \\
\hline & $\begin{array}{c}\text { Motor } \\
\text { impulsiveness }\end{array}$ & 0.08 & 0.02 & 0.30 & 0.213 & .832 & 0.502 & .479 \\
\hline & $\begin{array}{l}\text { Non-planning } \\
\text { impulsiveness }\end{array}$ & -2.77 & -0.61 & 0.53 & -6.529 & $<.001$ & 1.725 & .190 \\
\hline & Total score & -2.35 & -0.23 & 1.90 & -2.457 & .014 & 6.031 & .014 \\
\hline
\end{tabular}

In the Egyptian sample, females showed significantly higher means than males in self-control $(\Delta \mathrm{M}=-1.85 ; \mathrm{d}=-0.55 ; \mathrm{t}=$ $5.840 ; \mathrm{p}<.001)$ and non-planning impulsiveness $(\Delta \mathrm{M}=-2.77 ; \mathrm{d}$ $=-0.61 ; \mathrm{t}=-6.529 ; \mathrm{p}<.001)$. Significantly higher male than female standard deviations were detectable for attention $(\Delta \mathrm{SD}=$ $0.59 ; \mathrm{F}=10.190 ; \mathrm{p}=.002)$ and cognitive impulsiveness $(\Delta \mathrm{SD}=$ $0.74 ; \mathrm{F}=7.317 ; \mathrm{p}=.007)$. There were no factors with higher female than male standard deviation, therefore also the total score had greater male variability $(\Delta \mathrm{SD}=1.90 ; \mathrm{F}=6.031 ; \mathrm{p}=.014)$. 
On two factors, males scored higher than females with substantial effect size and statistical significance in the Saudi Arabian sample. These cases were attention $(\Delta \mathrm{M}=1.15 ; \mathrm{d}=0.52 ; \mathrm{t}=$ $5.201 ; \mathrm{p}<.001)$ and motor impulsiveness $(\Delta \mathrm{M}=2.27 ; \mathrm{d}=0.46 ; \mathrm{t}$ $=4.540 ; \mathrm{p}<.001)$, and the total score was also in favor of males $(\Delta \mathrm{M}=4.48 ; \mathrm{d}=0.44 ; \mathrm{t}=4.385 ; \mathrm{p}<.001)$. Males had higher standard deviations across all factors but with significance only in the cases attention $(\Delta \mathrm{SD}=1.68 ; \mathrm{F}=10.511 ; \mathrm{p}=.001)$, perseverance $(\Delta \mathrm{SD}=0.62 ; \mathrm{F}=10.568 ; \mathrm{p}=.001)$, and in the total score $(\Delta \mathrm{SD}=2.98 ; \mathrm{F}=13.495 ; \mathrm{p}<.001)$.

\subsection{Sex differences across cultures}

Table 4: Descriptive statistics of sex differences within the Saudi Arabian sample $(N=190$ males and $N=206$ females, $d f=$ 394). Positive numbers for $\Delta$ and $d$ represent higher values in the male sample, negative numbers higher values in the female sample.

\begin{tabular}{|c|c|c|c|c|c|c|c|c|}
\hline \multicolumn{2}{|r|}{ Factors } & \multicolumn{2}{|c|}{$M$} & \multirow{2}{*}{$\begin{array}{c}S D \\
\Delta \\
\end{array}$} & \multicolumn{2}{|c|}{$\begin{array}{c}\text { t-testforequality of } \\
\text { means }\end{array}$} & \multicolumn{2}{|c|}{$\begin{array}{l}\text { Levene's Test for } \\
\text { equality of variances }\end{array}$} \\
\hline Order & Scale & $\Delta$ & $d$ & & $t$ & $P$ & $F$ & $p$ \\
\hline \multirow{6}{*}{ First } & Attention & 0.81 & 0.23 & 1.68 & 2.246 & .025 & 10.511 & .001 \\
\hline & Motor & 0.72 & 0.15 & 0.58 & 1.503 & .134 & 0.489 & .485 \\
\hline & Self-control & -0.14 & -0.04 & 0.60 & -0.377 & .706 & 0.021 & .886 \\
\hline & Cognitive complexity & 1.05 & 0.35 & 0.61 & 3.481 & .001 & 3.096 & .079 \\
\hline & Perseverance & 1.15 & 0.52 & 0.62 & 5.201 & $<.001$ & 10.568 & .001 \\
\hline & Cognitive instability & 0.02 & 0.01 & 0.32 & 0.082 & .935 & 2.594 & .108 \\
\hline \multirow{4}{*}{ Second } & $\begin{array}{c}\text { Cognitive } \\
\text { impulsiveness }\end{array}$ & 1.20 & 0.32 & 1.35 & 3.198 & .001 & 10.299 & .001 \\
\hline & Motor impulsiveness & 2.27 & 0.46 & 0.70 & 4.540 & $<.001$ & 3.795 & .052 \\
\hline & $\begin{array}{l}\text { Non-planning } \\
\text { impulsiveness }\end{array}$ & 0.99 & 0.24 & 0.89 & 2.392 & .017 & 1.845 & .175 \\
\hline & Total score & 4.48 & 0.44 & 2.98 & 4.385 & $<.001$ & 13.495 & $<.001$ \\
\hline
\end{tabular}

(Culture and sexual differences ...) Khalid Ziada- Salaheldin Bakhiet - Ahmed Al-Shafey 


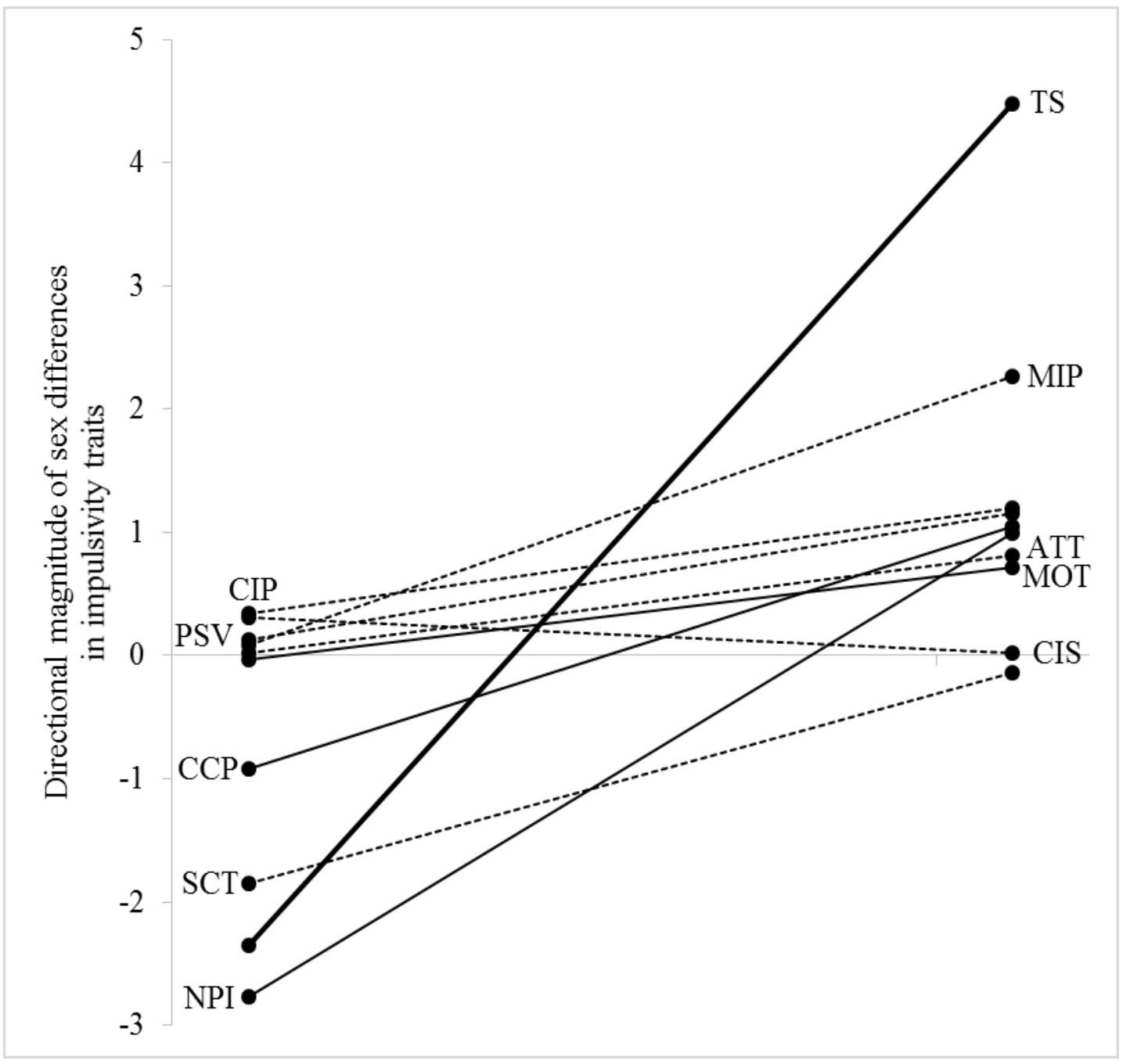

(Culture and sexual differences ...) Khalid Ziada- Salaheldin Bakhiet - Ahmed Al-Shafey 
Figure 1: Compared directional magnitudes $(\Delta M)$ of sex differences in impulsivity factors between the Egyptian sample (left) and the Saudi Arabian sample (right). Positive numbers represent higher male-impulsivity. Dotted lines represent no changes in direction, bold line represents total score. Coding: Attention (ATT), Motor (MOT), Self-control (SCT), Cognitive complexity (CCP), Perseverance (PSV), Cognitive instability (CIS), Cognitive impulsiveness (CIP), Motor impulsiveness (MIP), Non-planning impulsiveness (NPI), and Total score (TS).

In fig. 1, we compare the directional magnitudes of sex differences for each variable between the two countries. Left dots represent Egypt and right dots Saudi Arabia. Lines connect same factor of the two cultures, dotted lines represent differences which do not change direction from one culture to the other, and the bold line represent the total score. It can be seen that in the case of motor $(\mathrm{M}($ Egy $)=-0.03 ; \mathrm{M}(\mathrm{Sau})=0.72)$, cognitive complexity $(\mathrm{M}($ Egy $)=-0.92 ; \mathrm{M}(\mathrm{Sau})=1.05)$, non-planning impulsiveness $(\mathrm{M}(\mathrm{Egy})=-2.77 ; \mathrm{M}(\mathrm{Sau})=0.99)$, and the total score $(\mathrm{M}($ Egy $)=-$ $2.35 ; \mathrm{M}(\mathrm{Sau})=4.48)$, the direction of sex differences changed. All others keep their directions and don't change their rakings, except cognitive instability $(\mathrm{M}(\mathrm{Egy})=0.31 ; \mathrm{M}(\mathrm{Sau})=0.02$; $\operatorname{Rank}($ Egy) $=2$; Rank. $($ Sau $)=8$; ranks from highest to lowest and without total score). In summary, sex differences in some traits of impulsivity changed their direction and magnitude rank between Egypt and Saudi Arabia, others keep their directions and magnitude ranks. 
Table 5: Comparison of absolute Cohen's d effect size of sex and culture on differences between means for the Egyptian sample (EGY) and Saudi Arabian sample (SAU).

\begin{tabular}{|c|c|c|c|c|c|}
\hline \multirow{2}{*}{\multicolumn{2}{|c|}{ Factors }} & \multicolumn{4}{|c|}{ Absolute effect sizes $(d)$ of mean differences } \\
\hline & & \multicolumn{2}{|c|}{ Sexual } & \multirow{2}{*}{ Comparison } & Cultural \\
\hline Order & Scale & EGY & SAU & & EGY vS. SAU \\
\hline \multirow{6}{*}{ First } & Attention & 0.01 & 0.23 & $\overline{<}$ & 0.35 \\
\hline & Motor & 0.01 & 0.15 & $<$ & 0.43 \\
\hline & Self-control & 0.55 & 0.04 & $<$ & 0.60 \\
\hline & $\begin{array}{c}\text { Cognitive } \\
\text { complexity }\end{array}$ & 0.37 & 0.35 & $>$ & 0.33 \\
\hline & Perseverance & 0.07 & 0.52 & $<$ & 0.97 \\
\hline & $\begin{array}{l}\text { Cognitive } \\
\text { instability }\end{array}$ & 0.16 & 0.01 & unclear & 0.12 \\
\hline \multirow{4}{*}{ Second } & $\begin{array}{c}\text { Cognitive } \\
\text { impulsiveness }\end{array}$ & 0.09 & 0.32 & $<$ & 0.45 \\
\hline & $\begin{array}{c}\text { Motor } \\
\text { impulsiveness }\end{array}$ & 0.02 & 0.46 & $<$ & 0.89 \\
\hline & $\begin{array}{l}\text { Non-planning } \\
\text { impulsiveness }\end{array}$ & 0.61 & 0.24 & unclear & 0.37 \\
\hline & Total score & 0.23 & 0.44 & $<$ & 0.74 \\
\hline
\end{tabular}

Finally, we compared the absolute effect sizes for differences which we calculated for sex in the Egyptian and Saudi Arabian samples with the absolute effect size for culture in table 5. For six of nine factors and the total score of impulsivity, culture showed a stronger effect size than sex, and only in one case (cognitive complexity) this was inverted. For cognitive instability, culture showed a stronger effect than sex in the Egyptian sample but not in the Saudi Arabian sample. For non-planning impulsiveness, 
culture showed a stronger effect than sex in the Saudi Arabian sample but not in the Egyptian sample.

\section{Discussion and Conclusion}

This study was done to track sex differences and cultural differences, as well as cross-cultural differences between sex differences in impulsivity, in two under-researched Arabian or Middle Eastern countries.

The cross-cultural pattern of impulsiveness was surprising, as it contradicts superficial cultural divisions, which underlines the relevance of more complex systematics for cultural groups. The differences in impulsiveness in general or the different factors of the BIS-11 occurred unsystematically between the four nations compared and the dividing line does not run between the Western World and the Arab World. Instead, specific cultural aspects seem more important but difficult to explain. Hofstede's cultural dimension of power distance seems to be associated with cognitive impulsiveness. Power distance describes the willingness of weaker members of a society to accept unequal distributions

Our first hypothesis was confirmed by some of the results. The students from the Saudi Arabian sample are on average more impulsive than the students from the Egyptian sample. Although this is not the case in all factors and without moderate significance. The second hypothesis, about sex differences in favor of males, was only confirmed in Saudi Arabia, to boot partial and weak, whereas the Egyptian sample does not permit a 
clear statement, due to a lack of significance. As we tested sex differences not only for means but also for variance, we can say that in both samples, males showed higher standard deviations across all factors and the total score, but differences are larger, with stronger effect size and more frequently significant in the Saudi Arabian sample. This leads to the third hypothesis. As shown in figure 1, there were some differences not only in magnitude but also direction of sex differences and factor rankings. Because the Saudi Arabian sample is similar to samples from studies in other countries, we would like to call the Egyptian sample, with some reservation, a "special case". We were also surprised by the fact that cultural differences were so much stronger than sex differences, even in such similar cultures.

This is overall an interesting phenomenon which cannot be explained in this study. For future research, we propose that the answer may be hidden not only in basic differences in the conditions of life, but also in the malleability of impulsivity by short-term environmental or social changes, as has been found for collective shocks by Quinlan, Dira, Caudell, and Quinlan (2016). Such shocks could be for example the Arabian Spring, which happened in Egypt but not in Saudi Arabia. In addition, greater prosperity in Saudi Arabia than in Egypt is a possible cause. Otherwise, the changes reported by Quinlan et al. (2016) were only in the magnitude of the mean impulsivity of a whole population. They did not observe a reversal of sex differences. 
Otherwise, responses to environmental factors may depend on genetic predispositions, which account for up to $50 \%$ of the within-group variance in impulsivity (Bezdjian, Baker, \& Tuvblad, 2011). One identified genetic factor, the MAOAuVNTR polymorphism associated with impulsivity (Contini, Marques, Garcia, Hutz, \& Bau, 2006; Kolla et al., 2015, 2016), could play a role in "cultural" differences because it shows strong frequency variations between country populations (Way \& Lieberman, 2010). Genetic factors should be taken into account in further research about cross-cultural differences in impulsivity.

The third possibility is that measurement errors occur when using the same scale or test in different cultures. As Allik (2005) wrote, such errors may be caused by "inappropriate translations, biased sampling, or the non-identical response styles of people from different cultures". This is unlikely to be the case in our study because the same test version with the same translation was used by us with the same implementations in very similar samples (university students).

In conclusion, because the findings fit only partly with the current state of research, replications with other scales for impulsivity especially with Egyptian samples should be done as well as correlation- and path-analysis which include factors with possible influence on impulsivity. 


\section{References}

Allik, J. (2005). Personality dimensions across cultures. Journal of Personality Disorders, $\quad 19, \quad 212-232$. doi:10.1521/pedi.2005.19.3.212

Ammerman, B. A., Kleiman, E. M., Uyeji, L. L., Knorr, A. C., \& McCloskey, M. S. (2015). Suicidal and violent behavior: The role of anger, emotion dysregulation, and impulsivity. Personality and Individual Differences, 79, 57-62. doi:10.1016/j.paid.2015.01.044

Barkley-Levenson, E., \& Fox, C. (2014). The surprising relationship between indecisiveness and impulsivity. Personality and Individual Differences, 90, 1-6. doi:10.1016/j.paid.2015.10.030

Barratt, E. S. (1959). Anxiety and impulsiveness related 10 psychomotor deficiency. Perceptual and Motor Skills, 9, 191-198. doi:10.2466/PMS.9.3.191-198

Bezdjian, S., Baker, L.A., \& Tuvblad, C. (2011). Genetic and environmental influences on impulsivity: A meta-analysis of twin, family and adoption studies. Clinical Psychology Review, 31, 1209-1223. doi:10.1016/j.cpr.2011.07.005

(Culture and sexual differences ...) Khalid Ziada- Salaheldin Bakhiet - Ahmed Al-Shafey 
Brewis, A., Schmidt, K. L., \& Sánchez Casas, C. A. (2003). Crosscultural study of the childhood developmental trajectory of attention and impulse control. International Journal of Behavioral Development, 27, 174-181. doi:10.1080/01650250244000173

Burns, G. L., Walsh, J. A., Gomez, R., \& Hafetz, N. (2006). Measurement and structural invariance of parent ratings of ADHD and ODD symptoms across gender for American and Malaysian children. Psychological Assessment, 18, 452-457. doi:10.1037/1040-3590.18.4.452

Chahin, N., Cosi, S., Lorenzo-Seva, U., \& Vigil-Colet, A. (2010). Stability of the factor structure of Barrat's Impulsivity Scales for children across cultures: A comparison of Spain and Colombia. Psicothema, 22, 983-989.

Chapple, C. L., \& Johnson, K. A. (2007). Gender differences in impulsivity. Youth Violence and Juvenile Justice, 5, 221-234. doi:10.1177/1541204007301286

Contini, V., Marques, F. Z. C., Garcia, C. E. D., Hutz, M. H., \& Bau, C. H. D. (2006). MAOA-uVNTR polymorphism in a Brazilian sample: Further support for the association with (Culture and sexual differences ...) Khalid Ziada- Salaheldin Bakhiet - Ahmed Al-Shafey 
impulsive behaviors and alcohol dependence. American Journal of Medical Genetics Part B (Neuropsychiatric Genetics), 141B, 305-308. doi:10.1002/ajmg.b.30290

Cozzi, P., Putnam, S. P., Menesini, E., Gartstein, M. A., Aureli, T., Calussi, P., \& Montirossoa, R. (2013). Studying cross-cultural differences in temperament in toddlerhood: United States of America (US) and Italy. Infant Behavior \& Development, 36, 480483. doi:10.1016/j.infbeh.2013.03.014

Cross, C. P., Copping, L. T., \& Campbell, A. (2011). Sex differences in impulsivity: A metaanalysis. Psychological Bulletin, 137, 97-101. doi:10.1037/a0021591

Cyders, M. A. (2013). Impulsivity and the sexes: Measurement and structural invariance of the UPPS-P Impulsive Behavior Scale. Assessment, 20, 86-97. doi:10.1177/1073191111428762

Eysenck, S. B. G., \& Jamison, R. N. (1986). A cross-cultural study of personality. Journal of Social Behavior and Personality, 1, 190-208.

(Culture and sexual differences ...) Khalid Ziada- Salaheldin Bakhiet - Ahmed Al-Shafey 
Ferguson, Ch. J. (2009). An Effect Size Primer: A Guide for Clinicians and Researchers. Professional Psychology: Research and Practice, 40, 532-538.

Hadiyono, J. E. P., \& Kahn, M. W. (2010). Personality differences and sex similarities in American and Indonesian college students. The Journal of Social Psychology, 125, 703-708. doi:10.1080/00224545.1985.9713542

Hahn, A. M., Simons, R. M., \& Hahn, Ch. K. (2016). Five factors of impulsivity: Unique pathways to borderline and antisocial personality features and subsequent alcohol problems. Personality and Individual Differences, 99, 313-319. doi:10.1016/j.paid.2016.05.035

Hecht, L. K., \& Latzman, R. D. (2015). Revealing the nuanced associations between facets of trait impulsivity and reactive and proactive aggression. Personality and Individual Differences, 83, 192-197. doi:10.1016/j.paid.2015.04.021

Kolla, N. J., Dunlop, K., Downar, J., Links, P., Bagbya, R. M., Wilson, A. A., ... Meyera, J. H. (2016). Association of ventral striatum monoamine oxidase-A binding and functional (Culture and sexual differences ...) Khalid Ziada- Salaheldin Bakhiet - Ahmed Al-Shafey 
connectivity in antisocial personality disorder with high impulsivity: A positron emission tomography and functional magnetic resonance imaging study. European Neuropsychopharmacology, 26 , 777-786. doi:10.1016/j.euroneuro.2015.12.030

Kolla, N. J., Matthews, B., Wilson, A. A., Houle, S., Bagby, R. M., Links, ... Meyer, J. H. (2015). Lower monoamine oxidase-A total distribution volume in impulsive and violent male offenders with antisocial personality disorder and high psychopathic traits: An [(11)C] Harmine Positron Emission Tomography Study. Neuropsychopharmacology, $\quad 40, \quad 2596-2603$. doi:10.1038/npp.2015.106

Kulendran, M., Patel, K., Darzi, A., \& Vlaev, I. (2016). Diagnostic validity of behavioural and psychometric impulsivity measures: An assessment in adolescent and adult populations. Personality and Individual Differences, $90, \quad 347-352$. doi:10.1016/j.paid.2015.11.026

Lozano, J. H. (2015). Are impulsivity and intelligence truly related constructs? Evidence based on the fixed-links model. Personality (Culture and sexual differences ...) Khalid Ziada- Salaheldin Bakhiet - Ahmed Al-Shafey 
and Individual Differences, $\quad 85, \quad 192-198$. doi:10.1016/j.paid.2015.04.049

Magnússon, P., Smári, J., Grétarsdóttir, H., \& Prándardóttir, H. (1999). Attention-deficit/hyperactivity symptoms in Icelandic schoolchildren: Assessment with the Attention Deficit/Hyperactivity Rating Scale-IV. Scandinavian Journal of Psychology, 40, 301-306. doi: 10.1111/1467-9450.404130

Malesza, M., \& Ostaszewski, P. (2016). Dark side of impulsivity Associations between the Dark Triad, self-report and behavioral measures of impulsivity. Personality and Individual Differences, 88, 197-201. doi:10.1016/j.paid.2015.09.016

Maneiro, L., Gómez-Fraguela, J. A., Cutrín, O., \& Romero, E. (2017). Impulsivity traits as correlates of antisocial behaviour in adolescents. Personality and Individual Differences, 104, 417422. doi:10.1016/j.paid.2016.08.045

Moreno, M. J. G., Iza, C. V., Dolado, A. M., \& Palomo, S. M. (2011). Utility of Barrat Scale to measure impulsivity in a series of cases with behavioral variant-frontotemporal lobar 
degeneration (bv-FTD). Alzheimer's \& Dementia: Journal of the Alzheimer's Association, 7, S274. doi:10.1016/j.jalz.2011.05.784

Patton, J., Stanford, M., \& Barratt, E. (1995). Factor structure of the Barratt Impulsiveness Scale. Journal of Clinical Psychology, 51, 768-774. doi:10.1002/1097-4679(199511)51:6<768::AIDJCLP2270510607>3.0.CO;2-1

Quinlan, R. J., Dira, S. J., Caudell, M., \& Quinlan, M. B. (2016). Culture and psychological responses to environmental shocks. Cultural ecology of Sidama impulsivity and niche construction in Southwest Ethiopia. Current Anthropology, 57, 632-652. doi:10.1086/688213

Sperry, S. A., Lynam, D. R., Walsh, M. A., Hortond, L. E., \& Kwapil, Th. R. (2016). Examining the multidimensional structure of impulsivity in daily life. Personality and Individual Differences, 94, 153-158. doi:10.1016/j.paid.2016.01.018

Stanford, M., Mathias, C., Dougherty, D., Lake, S., Anderson, N., \& Patton, J. (2009). Fifty years of the Barratt Impulsiveness Scale: An update and review. Personality \& Individual Differences, 47, 385-395. doi:10.1016/j.paid.2009.04.008

(Culture and sexual differences ...) Khalid Ziada- Salaheldin Bakhiet - Ahmed Al-Shafey 
Velotti, P., \& Garofalo, C. (2015). Personality styles in a nonclinical sample: The role of emotion dysregulation and impulsivity. Personality and Individual Differences, 79, 44-49. doi:10.1016/j.paid.2015.01.046

Wardell, J. D., Quilty, L. C., \& Hendershot, C. S. (2016). Impulsivity, working memory, and impaired control over alcohol: A latent variable analysis. Psychology of Addictive Behaviors, advance online publication. doi:10.1037/adb0000186

Way, B. M., \& Lieberman, M. D. (2010). Is there a genetic contribution to cultural differences? Collectivism, individualism and genetic markers of social sensitivity. SCAN, 5, 203-211. doi:10.1093/scan/nsq059

Weafer, J., \& de Wit, H. (2014). Sex differences in impulsive action and impulsive choice. Addictive Behavior, 39, 1573-1579. doi:10.1016/j.addbeh.2013.10.033

Weinstein, A., \& Dannon, P. (2015). Is impulsivity a male trait rather than female trait? Exploring the sex difference in impulsivity. Current Behavioral Neuroscience Reports, 2, 9-14. doi:10.1007/s40473-015-0031-8

(Culture and sexual differences ...) Khalid Ziada- Salaheldin Bakhiet - Ahmed Al-Shafey 
Wenner, C. J., Bianchi, J., Figueredo, A. J., Rushton, J. Ph., \& Jacobs, W. J. (2013). Life History Theory and social deviance: The mediating role of executive function. Intelligence, 41, 102113. doi:10.1016/j.intell.2012.11.004

Yago, S., Hirose, T., Kawamura, A., Omori, T., \& Okamitsu, M. (2015). Gender, age, and cultural differences in the Japanese version of the Infant-Toddler Social and Emotional Assessment. Journal of Medical and Dental Sciences, 62-91, 101. doi:10.11480/jmds.620402. 


\section{ملخص}

الاندفاعية (أو الاندفاع) هو سمة نفسية لها تاريخ طويل في مجال البحثي وعلاقات كبيرة مع السمات الأخرى والحياة اليومية. وعلى الرغم من ظهور فروق في الاندفاعية بين الذكور والإناث إلا أنها بحاجة إلى مزيد من التأكيد. كذلك ظهرت فروق بين الدول أو التقافات في سمة الاندفاعية، ولكن عينات قليلة من إنه دول العربية بوجه عام. في هذه الدراسة استخدمنا عينتين، واحدة من المصربين (N = 450) والأخرى من المملكة العربية السعودية (N = 396) من طلبة الجامعة من الجنسين، وذلك لسد هذه الفجوة وملاحظة الفروق بين الجنسين وبين الثقافتين في سمة الاندفاعية. وجدت الدراسة الحالية فروق ثقافية مع وجود مستويات أعلى من الاندفاعية في المملكة العربية السعودية مقارنة بما ظهر في مصر • كما وجدت فروق بين الجنسين لبس فقط في المقدار ولكن أيضًا في الاتجاه في سمة الاندفاعية. حيث أظهر الذكور السعوديين متوسطات أعلى في سمة مقارنة بالإناث في حين أظهرت الإناث المصريات مستويات أعلى في سمة الاندفاعية مقارنة بالذكور ـ كما أن الفروف بين الثقافات أكبر منها بين الجنسين في هذه السمة.

الكلمات المفتاحية: الاندفاعية، عبر الثقافات، الفروق بين الجنسين، مصر، السعودية، الطلاب 